Max Deeg

\title{
Describing the Own Other: Chinese Buddhist Travelogues Between Literary Tropes and Educational Narratives
}

\author{
In his monumental Naturalis Historia, the famous Roman encyclopedist Pliny \\ the Elder (AD 23-79) gives us the following description of India:
}

For the peoples of the more civilised Indian races are divided into many classes in their mode of life: they cultivate the land, others engage in military service, others export native merchandise and import goods from abroad, while the best and wealthiest administer the government and serve as judges and counsellors of the kings. There is a fifth class of persons devoted to wisdom, which is held in high honours with these people and almost elevated into a religion; those of this class always end their life by a voluntary death upon a pyre to which they have previously themselves set light. There is one class besides these, half-wild people devoted to the laborious tasks - from which the classes above mentioned are kept away - of hunting and taming elephants; these they use for ploughing and for transport, these are their commonest kind of cattle, and these they employ when fighting in battle and defending their country: elephants to use in war are chosen for their strength and age and size. ${ }^{1}$

On the same topic, the Chinese historian Fan Ye 范瞱 (398-445), in his HouHanshu, "History of the Later Han," says the following:

The kingdom of Tianzhu (India) is [also] called Shendu; [it] is located several thousand li
southeast of the Yueshi. The customs are the same as the Yueshi, [but the land] is humid
and hot. Its kingdoms adjoin the Great Water. In battle [they] ride on elephants. Its people
are weaker than the Yueshi, [and they] practice the Way of the Buddha (futu 浮圖) and
therefore have made nonkilling their habit. All land [that has] the kingdoms of the Yueshi
and Gaofu to the west, extends to the Western Ocean in the south, [and] extends to Panqi
in the east belongs to Shendu. Shendu has several hundreds of independent cities, [and

1 Pliny, Natural History 6.22: namque vita mitioribus populis Indorum multipertita degitur: tellurem exercent, militia alii capessunt, merces alii suas evehunt externasque invehunt, res publicas optumi ditissimique temperant, iudicia reddunt, regibus adsident. quintum genus celebratae illis et prope in religionem versae sapientiae deditum voluntaria semper morte vitam accenso prius rogo finit. unum super haec est semiferum ac plenum laboris immensi - a quo supra dicta continentur - venandi elephantos domandique; is arant, is invehuntur, haec maxime novere pecuaria, his militant dimicantque pro finibus: dilectum in bella vires et aetas atque magnitude faciunt. Text and translation Harris Rackham, Pliny: Natural History, vol. 2, Libri III-VII, Loeb Classical Library (Cambridge, MA: Harvard University Press; London: William Heinemann Ltd., 1961), 386-389. 
each] city installs [its own] governor. There are tens of independent kingdoms, [and each] kingdom has [its own] king. Although each of them is a little bit different, they all together are called Shendu. At that time it belonged to the Yueshi. The Yueshi killed its king and installed a commander to rule it. The land produces elephants, rhinoceroses, tortoise shells, gold, silver, copper, iron, lead, and tin, [and since] it trades with Daqin in the west, it also gets the treasures of Daqin. There is also muslin, high-quality woolen cloth, different [kinds of] incense, "stone honey" (cane sugar), pepper, ginger, and black salt. ${ }^{2}$

The comparison of Pliny's description of India and the one by Fan Ye 范瞱 (398-445) in the Hou-Hanshu provides a couple of starting points for the subsequent discussion of Chinese Buddhist travelogues and their position in the broader Chinese literary discourse of much of the first millennium and beyond. Pliny focuses on aspects and features of India that are of political (government), social (caste system), and military interest (elephants), and only mentions and repeats the topos that earlier sources contain with reference to the gymnosophists, the wise men of India. ${ }^{3}$ Fan Ye follows earlier models of the description of foreign regions, but is the first official Chinese historiographer to give some information about Indian religion, claiming that Indians are exclusively Buddhist and do not kill. It seems clear where this idealized information may have come from: when he finished his work in 445, Fan Ye probably had access to such records on India as Shi Daoan's 釋道安 (312-385) Xiyu-zhi 西域志, “Record of the Western Regions," or maybe even Faxian’s 法顯 Foguo-ji 佛國記, “Record of the Buddhist Kingdoms."

What unites these texts and others, normally but not quite correctly called "pilgrim records," is the common background of their authors. They were all written and compiled by Buddhists, monks, or, in just three cases, by laymen (Song Yun, Wei Jie, and Wang Xuance; see below) who had traveled to the homeland of their religion. Although I would not speak of a specific genre in

2 Hou-Hanshu 後漢書 86, Xiyu-zhuan 西域傳: 天竺國一名身毒, 在月氏之東南數千里。俗與月氏同, 而卑治暑熱。其國臨大水。乘象而戰。其人弱於月氏, 脩浮圖道, 不殺伐, 遂以成俗。從月氏、 高附國以西, 南至西海, 東至磐起國, 皆身毒之地。身毒有別城數百, 城置長。別國數十, 國 置王。雖各小異, 而俱以身毒為名, 其時皆屬月氏。月氏殺其王而置將, 令統其人。土出象、犀、 玳琩、金、銀、銅、鐵、鉛、錫, 西與大秦通, 有大秦珍物。又有細布、好毾雎、諸香、石蜜、 胡椒、薑、黑鹽。See also John E. Hill, Through the Jade Gate - China to Rome: A Study of the Silk Routes 1st to 2nd Centuries CE: An Annotated Translation from the Hou Hanshu, "The Chronicle on the Western Regions,” rev. ed. (n.p.: John E. Hill, 2015), 31, from whose translation I differ in places.

3 See Klaus Karttunen, India in Early Greek Literature (Helsinki: Finnish Oriental Society, 1989), 217-219; Klaus Karttunen, India and the Hellenistic World (Helsinki: Finnish Oriental Society, 1997), 55-57. 
the light of their diversity of form, structure, and content, ${ }^{4}$ some of the texts obviously share some features. As partly ideological constructions of foreign regions, particularly of India, they express, as alluded in the title, a Buddhist worldview that is informed by more general Buddhist cosmological ideas seen from a Chinese perspective. In this worldview, the agents, being at once Buddhist and Chinese, try to mediate the tension, experienced by Chinese Buddhists, of being culturally Chinese and religiously "Indian"; it tries, in a way, to come to terms with the (Buddhist) own and (Indian) other at the same time. ${ }^{5}$ Quite naturally, these Buddhists focused on Buddhist concerns, such as the situation of the Buddhist sangha, monasteries, and stūpas, as well as narratives linked to the sacred geography of the respective places or regions described, but also followed inherited patterns of Chinese "xenology," the means of describing the foreign or other.

Collecting and recording information about foreign regions has a long tradition in China, starting with the first official dynastic history, the (Qian-) Hanshu (前)漢書, compiled by Ban Biao 班彪 (3-54 CE) and his son Ban Gu 班 固 (32-92 CE). This information was usually collected at the end of the thematic chapters (zhuan 傳) following the annalistic ( $j i$ 記) or biographical parts of the works, and comprised data such as the distance from the imperial capital, the geographical and political situation, the number of households, and information about social customs in the respective regions, but often not much about religious concepts and practices.

This "traditional" format was taken over in part by the earlier Buddhist descriptions of foreign countries, which, as could be expected, added information about Buddhism in the regions or countries described. Unfortunately, most of these early records, such as the (Shi-Daoan-)Xiyu-zhi (釋道安)西域志 of Shi Daoan 釋道安, certainly the most active and broadly interested Chinese scholar-monk of

4 I therefore disagree with Nancy Elizabeth Boulton, "Early Chinese Buddhist Travel Records as a Literary Genre” (PhD diss., Georgetown University, 1982), who suggests that the records form a genre of their own due to the shared topic and subthemes.

5 On the situatedness of Chinese Buddhists between a Chinese cultural and a Buddhist religious identity, see Max Deeg, “Chongu 'biandi qingjie': Han chuan fojiao zhong dui Yindu de zhujian rongshou” 重估“边地情结”: 汉传佛教中对印度的逐渐容受 [“Borderland complex” reloaded: Coming to terms with India in Chinese Buddhism], in Zhongyin guanxi yanjiu de shiye $y u$ qianjing 中印关系研究的视野与前景, eds. Shen Dansen 沈丹森 and Sun Yinggang 孙英刚 (Shanghai: Fudan-daxue-chubanshe 復旦出版社, 2016), 65-76. On the "geographical” aspect of this process, see Max Deeg, "Mapping Common Territory - Mapping Other Territory," Acta Orientalia Vilniensia 8, no. 1 (2008): 145-161. 
his time, ${ }^{6}$ are no longer extant, so we know next to nothing about their format, structure, and content. From Daoan's compilation, at least a few fragments are quoted in fascicle 797 of the Song encyclopedia Taiping-yulan 太平御覽 and - if we accept the identification of the Shishi-Xiyu-ji 釋氏西域記, “Record of the Western Regions [by a Follower] of the Clan of the Sākya,” with Daoan's work ${ }^{7}$ in the Shuijing-zhu 水經注, “Annotations to the 'Classic of Rivers,"” by Li Daoyuan 麗道元 (†527); ${ }^{8}$ these fragments seem to demonstrate that the work mainly contained information about the Buddhist background of a specific region. As an example, I provide the excerpt from the Xiyou-zhi quoted in the Taiping-yulan:

Juyi: ${ }^{9}$ The "Record of the Western Regions" of Shi Daoan says, "The kingdom of Juyi is several hundred $l i$ to the north of the city. On top of a mountain there is a camel made of stone [from which] water is dripping down; [if one] fetches it with vessels made of gold, copper, iron, or wood [or] with the palms of the hand it all leaks out, [and] only [vessels made of] gourd do not leak; consuming it makes the body stink, and hair and skin come off [such that one] should stop [consuming it]. The brāhmanas of this kingdom are guarding [it].” Boluonaisi ${ }^{10}$ (Vārānasîn): The "Record of the Western Regions” of Shi Daoan says, "[In] the kingdom of Boluonaisi, the Buddha has turned the wheel of the dharma [and] Devadatta went to hell, [and] the place [where] the ground sank in is still there in this country." The [kingdom of] the king of the rats: The "Record of the Western Regions" of Shi Daoan says, "On the way to Yutian (Khotan) there is the kingdom of the king of the rats, the big ones [as big] as dogs, the small ones [as small] as rabbits; [the king] wears a golden kāṣāya, [and] the śramaṇas transgress [the] rules

\footnotetext{
6 On Daoan, see Erich Zürcher, The Buddhist Conquest of China - The Spread and Adaptation of Buddhism in Early Medieval China, 3rd ed. (Leiden: Brill, 2007), 180-204, as well as Max Deeg, Das Gaoseng-Faxian-zhuan als religionsgeschichtliche Quelle. Der älteste Bericht eines chinesischen buddhistischen Pilgermönchs über seine Reise nach Indien mit Übersetzung des Textes (Wiesbaden: Otto Harrassowitz, 2005), 31-34.

7 Luciano Petech, “La description des pays d'occident de Che Tao-ngan,” in Mélanges de sinologie offerts à Monsieur Paul Demiéville, vol. 1 (Paris: Presses Universitaires de France, 1966), 169-170; Luciano Petech, "Note additionelle sur la 'Description des pays d'occident' de Che Tao-ngan,” in Mélanges de sinologie offerts à Monsieur Paul Demiéville, vol. 2 (Paris: Presses Universitaires de France, 1974), 399-401.

8 The fragments have been translated and discussed by Luciano Petech, Northern India according to the Shui-Ching-Chu (Rome: Is.M.E.O., 1950).

9 拘夷 / *kuě-ji. All reconstructed Early Middle Chinese forms marked with an asterisk $\left(^{\star}\right)$ follow Edwin G. Pulleyblank, Lexicon of Reconstructed Pronounciation in Early Middle Chinese, Late Middle Chinese, and Early Mandarin (Vancouver: University of British Columbia Press, 1991). Juyi looks like an abbreviated form of Juyinajie 拘夷那竭 / ^kuě-ji-na'-giat or Jushinajia 拘尸那竭 / `kuě-şi-na’-giat, Kuśinagara, but has been identified contextually as a transliteration of Kuča: Petech, “La description des pays d'occident,” 169-170.

10 波羅奈斯 / * $p a-l a-n a^{h}$-si.
} 
and have no etiquette, [while] the white-robed [laypeople] always harm people."11 Mohelai ${ }^{12}$ (Mahārāștra): The "Record of the Western Regions" of Shi Daoan says, "The kingdom of Mohelai again extends to the kingdom of Helai in the south; there is the Anouda ${ }^{13}$ (Anavatapta) mountain, [and] the city [known as] 'Royal Residence'14 (Rājagrha) is [situated] at the southeastern corner of the [A]nouda mountain; the 'Bamboo Grove' monastery ${ }^{15}$ (Venuvana-vihāra) is west of the city; the aśvattha tree [under which] the Buddha practiced austerities for six years is fifty li from the city." Boliyue: ${ }^{16}$ The "Record of the Western Regions" of Shi Daoan says, "The kingdom of Luowei ${ }^{17}$ [measures] four hundred $l i$ from east to west [and] extends to the kingdom of Boliyue. The kingdom of Boliyue is the kingdom of the Buddha's maternal grandfather."18

As can be seen, Daoan already includes India (Kuśinagara, Mahārāṣṭa, Kapilavastu, Rājagṛha) as part of the Western Regions and is interested in the Buddhist or local legends linked to the different places. Otherwise, he seems to follow the established pattern of giving directions, measures, and maybe - in the original version - additional information.

11 The Tang dictionary Yiqiejing-yinyi 一切經音義, “Sounds and Meanings of All Sūtras”, compiled by Huilin 慧琳 (737-820), seems to reflect some of the older legends about the rats of Khotan, according to which the rats have golden fur (T.2128.706b.7f.). The remark on the evil behavior of the monks and laypeople may originate from the narratives around the corrupt sangha of Khotan in other texts.

12 摩訶賴 / *ma-xa-laj $j^{h}$. Petech, “La description des pays d'occident," 184, points out that the "geography" is confused here.

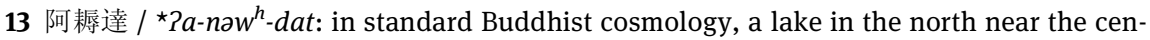
tral mountain (Su)meru. In the Tang period, Daoxuan 道宣 (596-667), in his Shijia-fangzhi 釋 迦方志, “Record of the Regions of Sākya[muni]," with reference to authoritative texts like the Shuijing-zhu and others, identifies Anavatapta mountain with the Kunlun 崑萹 range (T.2088.949b.23ff.).

14 Wangshe 王舍, the old capital of the kingdom of Magadha.

15 Zhuyuan-jingshe 竹園精舍.

16 波麗越 / “pa-l $l j^{h}$-wuat (?); as Petech (“La description des pays d'occident,” 182) has observed, this is a strange name for the kingdom of Koliya, the Buddha's grandfather's kingdom in the Buddhist texts.

17 Luowei 羅衛 is an abbreviated form of Jiaweiluowei 迦維羅衛 / ${ }^{\star} k \dot{i} a-j w i-l a-w i a j^{h}$ : Kapilavastu, the Buddha's hometown.

18 拘夷: 釋道安《西域志》曰: 拘夷國, 北去城數百里。山上有石駱駝, 溺水滴下, 以金、銅、 鐵及木器、手掌承之皆漏, 惟漂佮不漏, 服之令人身臭, 毛皮盡脫得止。其國有婆羅門守視。波 羅秦[em. 奈]斯: 釋道安《西域志》曰: 波羅秦斯國, 佛轉法輪, 調達入地獄, 土陷處, 皆在其 國。鼠王: 釋道安《西域志》曰: 于闐道中有鼠王國, 大者如狗, 小者如菟 [em. 兔], 著金袈 乷, 沙門過不禮, 白衣不禮軴害人。摩訶賴: 釋道安《西域志》曰: 摩訶賴國, 又南得訶賴 國, 有阿耨達山, 王舍城在耨達山東南角, 竹園精舍在城西。佛, 六年苦行貝多樹, 去城五十 里。波麗越: 釋道安《西域志》曰: 羅衛國東西四百里, 至波麗越國。波麗越國, 即佛外祖國也。 
What changed the authority and reliability of Buddhist reports about the Western Regions and, more particularly, about India - but not necessarily their descriptive framework - were the authentic reports of Chinese Buddhists who traveled to and within India. Most of these records have not survived and are only known from references in other and later works: Faxian's companion Baoyun 寶雲 (377-449) allegedly wrote a record (jizhuan 記傳) whose title is not known, but is referred to in Huijiao's 慧皎 Gaoseng-zhuan 高僧傳 (T.2059.340a.13f.), “Biographies of Eminent Monks" (ca. 530). ${ }^{19}$ In the year 439, Zhimeng 智猛 published his (Youxing-)Waiguo-zhuan 遊行外國傳, “Record of (Travels Through) the Foreign Kingdoms," mentioned in three dynastic histories (Suishu, Jiu-Tangshu, Xin-Tangshu) and in Daoxuan's Shijiafangzhi (T.2088.969b.9f.), on his travels to Central India between 404 and 437, paraphrased in the Gaoseng-zhuan. Daopu 道普 traveled after 424 and left a work with an unknown title. ${ }^{20}$ Fasheng 法盛 compiled a work called Liguozhuan 歷國傳, “Record of Traveling Through the Kingdoms," which is mentioned in the Suishu.

Only one of these records from the beginning of the fifth century has survived: Faxian's Foguo-ji, the "Record of the Buddhist Kingdoms." It is worth mentioning that Faxian, like Zhimeng in his record, did not follow the formal model of the historiographical zhuan, featuring information about the individual regions, but focuses on directions, distances, and Buddhist narratives linked to these regions. He gives, however, a rather idealized description of Central India after having passed through Mathurā: ${ }^{21}$

[The region] south of [of Mathurā] is called the Middle Kingdom. In the Middle Kingdom, the weather is moderate in summer and in winter, without frost and without snow. The people are wealthy and happy, and there is no [system of] registration and [no] state control. Only those who cultivate royal land have to return revenue. When they want to leave they go, [and] when they want to stay they stay. The king rules without corporeal punishment or capital punishment. Culprits only have to pay a fine according to the seriousness

19 The information has been collected by Édouard Chavannes, "Voyage de Song Yun dans l’Udyāna et le Gandhāra (518-522 p.C.),” Bulletin de l'École Française de l'Extrême-Orient 3 (1903): 430-441.

20 Daoxuan refers to a "big record" (dazhuan 大傳: T.2088.969c.8).

21 This passage is mistaken by Xuanzang as a description of Mathurā: see Max Deeg, "Has Xuanzang Really Been in Mathurā? Interpretatio Sinica or Interpretatio Occidentalia - How to Read Critically the Records of the Chinese Pilgrims," in Essays on East Asian Religion and Culture. Festschrift in Honour of Nishiwaki Tsuneki on the Occasion of His 65th Birthday, eds. Christian Wittern and Shi Lishan (Kyoto: Editorial Committee for the Festschrift in Honour of Nishiwaki Tsuneki, 2007), 35-73. 
of their crime. [Even if] they commit a crime for a second time, they only have their right hand cut off. The whole royal guard receives a salary. No citizens kill living beings, drink [spirits], or eat spicy food, except for the candāalas. Caṇdāla means "evil people"; they live separately from the others. When they go to the market in the city, they beat a piece of wood to distinguish themselves [from the others] - that the others recognize them and can avoid them [so that] they have no contact [with the other people]. In the kingdom [they] do not keep pigs or chicken and they sell no domesticated animals. There are no butchers in the markets and no liquor shop. For trading, cowry is used. Only the candālas are fishermen and hunters and sell meat.

After the Buddha [had entered] parinirvāna, all the kings, elders and clan leaders erected monasteries for the sangha and donated fields, houses, farms, fields, people, cows, and calves, [and these] donations were registered on iron plates; since then, [this custom] has been transferred from king to king and nobody dares abandon [it, so] the custom continues until nowadays.

All throughout the residences of the monks, there is no lack of bedding and blankets, of food or drink, of clothing. The monks are normally preoccupied with meritorious activity, such as reciting sūtras or sitting in meditation.

When guest monks arrive, the resident monks welcome them, carry their robes and alms bowls, and give them water for washing their feet, oil for their feet, and broth [as food normally] not to be consumed outside the permitted time for eating. After [the guest monks] have rested for a short time, they are asked for their ordination age and are given a room and bedding according to [their rank]. All of this [is arranged] according to the dharma.

Where the monks reside, stūpas for Saāriputra, Maudgalyāyana, and Ānanda stand erect, as well as for the [three pițakas,] Abhidharma-, Vinaya-, and Sūtra(-pițaka).

One month after the summer retreat, families who hope for merit (punya) produce liquid food to be donated to the monks and which can be consumed outside of the allocated time for meals. The great assembly of the monks expounds the dharma. After having expounded the dharma, they offer flowers, [fruit,] and incense to the stūpa of Sāriputra. Lamps are burning the whole night and dancers and musicians [perform scenes of] when Śāriputra still was a brāhmaṇa and visited the Buddha to ask him for permission to leave the household, as well as [scenes] concerning Mahāmaudgalyāyana and Mahākāśyapa.

The nuns (bhikșuṇi) only make offerings to the stūpa of Ānanda, since Ânanda asked the Venerable One to allow women to leave the household. The novices (śrāmanera) make offerings to Rāhula. The masters of the abhidharma make offerings to the [stūpas] of the abhidharma, [and] the masters of the vinaya to the [stūpas] of the vinaya. [These festivities] take place annually and have their [specific] date. When they are followers of the Mahāyāna, they make offerings to Prajñāpāramitā, Mañjuśrī, Avalokitasvara, and other [divine beings]. When the monks enter their next monastic year after the summer retreat, the elder, householders, brāhmanas, and others distribute robes and [other] things needed by the śramanas. The monks accept [these] and distribute them among themselves. These rules of behavior of the holy community have been transmitted continuously since the nirvāna of the Buddha. 
From where [Faxian and his companions] crossed the Indus to South India, to the Southern Sea, [the distance] is forty or fifty thousand li. [The land] is as flat [as] the ocean, and there are no big mountains or rivers. ${ }^{22}$

In Faxian's record, we first grasp what could be called an "ethno-topography of correspondence": the character and mentality (temperament, behavior, customs, etiquette, and - last but not least - religion) of the people correspond to the climate and geographical situation. Since Buddhism is supported, the country is prospering and the people are happy. This, as far as I can see, is a Buddhist innovation in this specific form, however building on a Chinese descriptive pattern that Needham has called "correlative thinking," i.e. the idea that all phenomena on different ontological levels (micro-, meso-, and macrocosms) are correlated. ${ }^{23}$ Later Buddhist records like Xuanzang's or Huichao’s 惠超 (who traveled before 729$)^{24}$ also follow this model.

22 859a. 凡沙河已西, 天竺諸國, 國王皆篤信佛法。供養眾僧時, 則脫天冠, 共諸宗親, 群臣 手自行食。行食已, 鋪壇於地, 對上座前坐, 於眾僧前不敢坐床。佛在世時, 諸王供養法式, 相 傳至今。從是以南, 名為中國。中國寒暑調和, 無霜, 雪。人民殷樂, 無戶籍官法; 唯耕王地者 乃輸地利, 欲去便去, 欲住便住。王治不用刑斬; 有罪者但罰其錢, 隨事輕重; 雖復謀為惡逆, 不過截右手而已。王之侍衛, 左右皆有供祿。舉國人民悉不殺生, 不飲酒, 不食葱蒜, 唯除斿茶 羅。斿茶羅名為惡人, 與人別居; 若入城市, 則擊木以自異, 人則識而避之, 不相唐突。國中不 養猪, 雞, 不賣生口; 市無屠酤及沽酒者; 貨易則用貝齒。唯斿茶羅, 獵師賣肉耳。自佛般泥洹 後, 諸國王, 長者, 居士為眾僧起精舍, 供給田, 宅, 園, 圃, 民戶, 牛, 犢, 鐵券書錄; 後王王 相傳, 無敢廢者, 至今不絕。眾僧住止房舍, 床莀, 飲食, 衣服, 都無缺乏, 處處皆爾。眾僧常 以作功德為業, 及誦經, 坐禪。客僧往到, 舊僧迎逆, 代擔衣鉢, 給洗足水, 塗足油, 與非時 漿, 須果; 息已, 復問其臘數, 次第得房舍, 臥具; 種種如法。眾僧住處, 作舍利弗塔, 目 連, 阿難塔, 並阿毘昙, 律, 經塔。安居後一月, 諸希福之家勸化供養僧, 作非時漿; 眾僧大 會說法。說法已, 供養舍利弗塔, 種種華香, 通夜然燈, 使伎樂人作'舍利弗本婆羅門時詣佛求 出家‘; 大目連, 大迦葉亦如是。諸比丘尼多供養阿難塔, 以阿難請世尊聽女人出家故。諸沙彌 多供養羅云。阿毘昙師者, 供飬阿毘曇。律師者, 供飬律。年年一供飬, 各自有日。摩訶衍 人, 則供養般若波羅蜜, 文殊師利, 觀世音等。眾僧受歲竟, 長者, 居士, 婆羅門等各持種種 衣物, 沙門所須, 以布施僧; 眾僧受亦自各各布施。佛泥洹已來, 聖眾所行威儀法則, 相承不 絕。自度新頭河, 至南天竺, 迄于南海, 四五萬里, 海平坦, 無大山川, 正有河水。See also Max Deeg, Das Gaoseng-Faxian-zhuan als religionsgeschichtliche Quelle, 263-268, 528-531.

23 Joseph Needham, Science and Civilisation in China, vol. 2, History of Scientific Thought (Cambridge: Cambridge University Press, 1956), particularly 280-281; see also Robert H. Sharf, Coming to Terms with Chinese Buddhism: A Reading of the Treasure Store Treatise (Honolulu: University of Hawai'i Press, 2002), 78-82.

24 An English translation of Huichao's (incomplete) travelogue is Yang Han-Sung, Jan YünHua, Iida Shotaro, and Laurence W. Preston, The Hye Ch'o Diary: Memoir of the Pilgrimage to the Five Regions of India (Berkeley: Asian Humanities Press, 1984); see also Donald S. Lopez, Jr., Hyecho's Journey: The World of Buddhism (Chicago: University of Chicago Press, 2017). 
For the individual regions, Faxian seems to refer to an idealized illo tempore, implicitly or sometimes explicitly applying a rhetoric of decline: what was a prosperous region at the time of the Buddha is mostly lying in decay. ${ }^{25}$ Instead of providing details, he is quite focused, as is to be expected, on giving information about the Buddhist sacred geography and the narratives attached to specific places and sites.

The next records partially preserved are those of Song Yun 宋雲, Senghui 慧生, and Daoyao 道藥 (or Daorong 道榮), from the beginning of the sixth century. Longer fragments contained in Luoyang-jialan-ji 洛陽伽藍記, “Record of the Monasteries of Luoyang," of Yang Xuanzhi 楊衒之 from around 547 only cover the Central Asian regions and the Indian Northwest, the region of Gandhāra. ${ }^{26}$ Besides giving information about Buddhist legends, Song Yun - as one might expect from the report of an official envoy of the Chinese court - also includes information about his encounter with the rulers of the Hephthalites, Udyāna (Swāt), and Gandhāra (the historical Hunnic king Mihirakula), as well as about distances and the political situation, partly in the style of the zhuan of the dynastic histories, but he mostly omits details about climate, people, and products.

The earlier travelers to India paved, as it were, the way for imperial contact in later times. Song Yun's mission, although not penetrating into the Indian and Buddhist heartland was, in a way, one of the first cases. However, before the religio-diplomatic missions of a later dynasty could take place successfully, the reunification of the realm had to be accomplished for the sake of political stability and a new true imperial outreach. When reunification finally happened, it led to the first peak in Sino-Indian relationships. A prelude to a concrete and increased diplomatic relationship with Indian states was the short-lived Sui 隋 dynasty's (581-618) special interest in the "Western Regions" (xiyu), which at that time clearly included India. ${ }^{27}$ But it was partly on Buddhists that the court re-

25 Scholars have taken this at face value and have used Faxian's and other travelers' information as a basis for reconstructing a general decline of Buddhism in India between the late fourth and seventh centuries (Xuanzang), without taking into account the religious backdrop of the Buddhist theory of the decline of the dharma, on which see Jan Nattier, Once upon a Future Time: Studies in a Buddhist Prophecy of Decline (Berkeley: Asian Humanities Press, 1991).

26 See the more recent translations by Wang Yi-t'ung, A Record of Buddhist Monasteries in Lo-yang by Yang Hsüan-chih (Princeton: Princeton University Press, 1984), and Jean Marie Lourme, Yang Xuanzhi: Mémoire sur les monastères bouddhiques de Luoyang (Paris: Les Belles Lettres, 2014).

27 I have discussed the following in Max Deeg, "When Peregrinus Is Not Pilgrim: The Chinese 'Pilgrims' Records - A Revision of Literary Genre and its Context," in Dharmayātra - Buddhist Pilgrimage in Time and Space, eds. Christoph Cueppers and Max Deeg (Lumbinī: Lumbinī International Research Institute, 2014), 85-87. 
lied when retrieving the information it wanted and needed. An eminent monk of the Sui period, Yancong 彥琮 $(557-610),{ }^{28}$ on the basis of information given by the Indian monk Dharmagupta/Damojueduo 達摩笈多 (active 590-619), wrote a record on imperial order, thematically arranged in ten chapters, ${ }^{29}$ called Dasui-xiguo-zhuan 大隋西國傳, “Record of the Western Kingdoms (Written under the) Great Sui,” aka Xiyu-zhuan 西域傳. ${ }^{30}$ Yancong cooperated

28 On Yancong, see Axel Held, "Der buddhistische Mönch Yen-Ts'ung (557-610) und seine Übersetzungstheorie” (PhD diss., University of Cologne, 1972).

29 T.2060.435c.20ff. 以笠多遊履具歷名邦, 見聞陳述事逾前傳, 因著大隋西國傳一部, 凡十 篇, 本傳：一方物, 二時候, 三居處, 四國政, 五學教, 六禮儀, 七飲食, 八服章, 九寶貨, 十盛列山河, 國邑, 人物。斯即五天之良史, 亦乃三聖之宏圖; 故後漢《西域傳》云 : “靈聖 之所降集, 賢懿之所挺生, 者是也。詞極綸綜, 廣如所述。“Because [Dharma]gupta had traveled through famous regions, and had reported information exceeding [what had been reported] in former reports, [Yancong] wrote the Dasui-xiguo-zhuan in ten chapters, truly recording: 1 . products; 2 . seasons; 3 . dwellings; 4. governmental affairs; 5 . teachings (religions); 6. etiquette; 7. eating and drinking; 8. clothing; 9. jewelry [and] money; 10. mountains, rivers, kingdoms, cities, [and] people. This is an excellent historical [work], even comparable with the Great Plan of the three saints (here probably the three 'cultural heroes' Yao 堯, Shun 舜, and Yu 禹); therefore, this is what is said in the 'Records of the Western Regions of the Later Han': 'What the saints have bestowed, what the sages have produced ....' [Even if] these words are extremely comprehensive [they describe] what is broadly said [in the record]." My translation differs considerably in some points from that of Held, "Der buddhistische Mönch Yen-Ts'ung,” 141-142. The Tang catalogue Datang-neidian-lu 大唐內典 錄 (T.2149.280a.24 and 332b.15) calls the ten sections "fascicles" (juan 卷). It is not clear if this is the same Xiguo-zhuan 西國傳 as mentioned in the Fahua(jing)-zhuanji 法華(經)傳記 (T.2068.79b.6), in a story about the Gomati monastery in Khotan or, in the same text, in a story about a monk rescuing a poisonous nāga in the mountains near Vārānasī who is in pain due to worms in his belly (80b.22), and another one about a foreign (waiguo 外國: Indian?) soothsayer (89b.16). In the same collection, there is a quotation from a Xiyu-zhi about Mahāyāna Buddhism in Khotan and Karghalik (Zhegoupan-guo 遮呴槃國; see 50.b.4ff.), the origin of which is not clear. The Xiguo-zhuan mentioned, however, seems to be a different text, concentrating on narratives: Sanbao-ganying-yaolüe-lu 三寶感應要略錄, “Essential Record of Stimulative Responses of the Three Jewels" (T.2084.827a.13), quotes it as one of the sources of its story of the famous first Buddha statue of King Udyana (Uḍdiyāna) of Roruka, and other Indian stories are taken from this source alone (841a.26, 845a.17, 852c.17). Another, similar collection mentioned in the Fahua-zhuanji is a Xiyu-zhuan 西域傳 (T.2068.73b.21).

30 XGT.2060.437c.3. In the same passage (437c.5ff.), it is mentioned that on imperial order, Yancong translated two works, the Sheli-ruitu-jing 舍利瑞圖經, “Sütra of the Auspicious Images of the Relics," and the Guojia-xiangrui-lu 國家祥瑞錄, “List of the Auspicious Signs in the Nation,” into Sanskrit (? fan sui wei fan 翻隋為梵) on behalf of an anonymous śramana from Rājagṛha (Wangshe-cheng 王舍城); these were arranged into ten fascicles that were then distributed to the kingdoms of the Western Region. These ten fascicles, however, may refer to a different work ascribed to Yancong, the Xiyu-xuanzhi 西域玄志, “Mysterious Report on the Western Regions," also in ten fascicles (FZ, T.2122.1022c.21, simply called Xiyu-zhi in the Datang-neidian- 
with the high Sui official Pei Ju 裴矩, an advisor of emperor Yangdi 楊帝 (r. 604-617), in compiling information on matters of the Western Regions. ${ }^{31}$ Pei $\mathrm{Ju}$, as a collector of "intelligence regarding Inner Asia" and an "indefatigable geographer and ethnographer,"32 authored a work called Xiyu-tuji 西域圖記 (in three fascicles), an "Illustrated Record of the Western Regions," which included maps of the more than forty kingdoms described. ${ }^{33}$ According to Yancong's biography in the Xu-gaoseng-zhuan 續高僧傳 (XGZ), Yancong and Peiju also coauthored a Tianzhu-ji 天竺記, “Records of India," ${ }^{34}$ which was probably a complement ${ }^{35}$ to Pei Ju's other work, which was mainly concerned with Central Asia. From this evidence, ${ }^{36}$ it is clear that the interest in Central Asia and India was not only motivated by religious devotion, ${ }^{37}$ but by an

$l u$, T.2149.280a.24 and 332b.15), which - if it really is identical with the compilation in ten fascicles mentioned in Yancong's biography (see below) - would be the only example of a Chinese text or compilation (probably based on Indian sources) translated into an Indic language: T.437c.

31 On Pei Ju, his life, and his political role, see Fritz Jäger, "Leben und Werk des P'ei Kü," Ostasiatische Zeitschrift 9 (1920-1922): 81-115, 216-231, and Arthur F. Wright, "The Sui Dynasty (581-617)," in The Cambridge History of China, vol. 3, Sui and T'ang China, 589-906, Part I, eds. Denis Twitchett and John K. Fairbank (London: Cambridge University Press, 1979), 127 passim.

32 Wright, “The Sui Dynasty (581-617),” 127.

33 Recorded in the Suishu 隋書 and Xin-Tangshu 新唐書 and repeated in FZ (T.2035.312a.20ff.). As there is no mention of Yancong in these sources, especially not in the Buddhist encyclopedias, this work is certainly not identical with Pei Ju's Tianzhu-ji, as Held, "Der buddhistische Mönch Yen-Ts'ung," 131, implies. Furthermore, in the reference to Pei Ju's work, the name for India is given as Bei-Poluomen 北婆羅門, “[the] northern [kingdom of] the brāhmana” (312a.29), instead of Tianzhu 天竺.

34 T.2060.437c.21f. 勅又令裴矩共琮修纘《天竺記》, 文義詳洽, 條貫有儀。“Furthermore, it was ordered that Pei Ju together with [Yan]cong should compile a 'Record of India,' the literary content [of which] was detailed and balanced, [and] the form [of which] was regular." See also the German translation by Held, "Der buddhistische Mönch Yen-Ts'ung," 61-62.

35 This seems to be suggested by the use of the word zuan 纘, “to continue, complement," in the biography.

36 A similar propagandistic and ideological agenda behind a growing interest in Buddhist India and its history under the Sui is reflected in Fei Zhangfang's 費張房 catalog Lidai-sanbaoji 歷代三寶記 (presented to the court in the year 597): see Max Deeg, “Zwischen Spannung und Harmonie: Das Problem von Chronologie und Synchronologie in der frühen chinesischen buddhistischen Historiographie," in Geschichten und Geschichte: Historiographie und Hagiographie in der asiatischen Religionsgeschichte, ed. Peter Schalk (Uppsala: Uppsala Universitet, 2010), 96-139.

37 In Yancong's case, this religious interest is reflected in his writing the biographies (zhuan 傳 or benzhuan 本傳) of the Indian monks Dharmagupta and Narendrayaśas/Naliantiyeshe 那連提耶舍 (517-589): see Held, “Der buddhistische Mönch Yen-Ts’ung,” 130ff. 
imperial agenda in the context of the policy of the unified Sui empire. This is also shown by the lost record, Xifan-ji 西番記, "Record of the Western Barbarians," of the Chinese envoy to Central Asia, Wei Jie 韋節, during the reign of the second and last Sui emperor Yangdi 煬帝 (605-616); the envoy made his way to Kaśmīr or Kapîsa (Jibin) and all the way to Rājagṛha in Central India. ${ }^{38}$ It is in this period that the collection of information about these foreign regions gained an official status, which can only be understood in a political and diplomatic context.

More consistent diplomatic relations with India, albeit only for a short period, were established in the second half of the reign of the second emperor of the Tang dynasty (618-907), Taizong 太宗 (r. 626-649); between 641 and 658, seven diplomatic missions (three Indian, four Chinese) went back and forth between Chang'an and the court of the North Indian Puṣpabhūti (Puṣyabhūti) ruler Harșavardhana Sīlāditya (ca. 590-647) of Kānyakubja (modern Kanauj), ${ }^{39}$ who also happened to rule the Buddhist heartland Magadha (today's Bihār), where most of the Buddhist sacred places were located. We do not know exactly what triggered these missions, ${ }^{40}$ but it is likely that they were linked, on the Chinese side, by the growing expansionism of emperor Taizong. Taizong's foreign policy was marked by a mixture of a specific version of "loose rein" 41 and imperial expansionism in the Western borderlands, which aimed at the flexibility of being prepared for conquest and for alliances with respect to individual regions in the "Western Regions." For realizing this policy, the court, like the Sui dynasty did before them, needed up-to-date and detailed information about as many regions as possible.

38 Chavannes, "Voyage de Song Yun," 438.

39 See the table in Tansen Sen, Buddhism, Diplomacy, and Trade: The Realignment of SinoIndian Relations, 600-1400 (Honolulu: University of Hawai'i Press, 2003), 21. There may have been a fourth tour to India by Wang Xuance before 663. Sen, Buddhism, Diplomacy, and Trade, 16 , mentions more than fifty missions in total between China and India between the years 619 and 753 (without giving the sources for this number). Hans Bielenstein, Diplomacy and Trade in the Chinese World, 589-1276 (Leiden: Brill, 2005), 72-77, lists twenty-three missions for roughly the same period.

40 I do not agree with the political implication of the statement of Sen, Buddhism, Diplomacy, and Trade, 17, that "Xuanzang was instrumental in turning Taizong's attention toward Buddhism and South Asia": Xuanzang returned in 645 after the first mission had already gone to India in 641.

41 Wang Bangwei 王邦維, Datang-xiyu-qiufa-gaoseng-zhuan-xiaozhu 大唐西域求法高僧傳校注 (Beijing: Zhonghua-shuju 中華書局, 2009), 262. 
Linked with three of the aforementioned Chinese missions is the name of the Tang official Wang Xuance 王玄策 (fl. 641-666). ${ }^{42}$ The mix of diplomatic and religious activities are very prominent in the case of Wang: on his third tour to India, on which he set off in the year 657 and from which he probably returned in 662, he had the imperial order to present a kāșāya at Bodhgayā and to bring the eminent Chinese monk Xuanzhao 玄照 back to China. ${ }^{43}$ Wang also set up inscribed stelae in Bodhgayā and on mount Gṛdhrakūta during his visit in the year $645 .{ }^{44}$ For Wang, we also have external evidence that he was a dedicated Buddhist in the form of an inscription - in the Buddhist caves of Longmen 龍門, near the eastern capital of Luoyang 洛陽, and dated to the year 665 - in which he expresses his devotion to the future Buddha Maitreya. ${ }^{45}$ Unfortunately, the record that Wang had written between 661 and 666, the Zhong-tianzhu-xingji 中天箨行記, “Report on Travels in Central India," in ten fascicles, is only preserved in some fragments quoted in other Buddhist works, but this suffices to gain a rough picture of Wang's missions and his record, ${ }^{46}$ although the fragments focus, of course, on Buddhist matters, maybe selected as complementary information to those contained in Xuanzang's "Record."

The "ultimate" Buddhist record, of course, is Xuanzang's Datang-Xiyu-ji 大唐西域記, “Record of the Western Regions of the Great Tang [Dynasty]," written between 645 and 646 by order and on behalf of the second Tang emperor, Taizong. The "Record" follows the historiographical tradition of giving detailed information about the individual regions, but focuses chiefly (though not exclusively) on the Buddhist legends linked to these places, mostly episodes from the life of the Buddha but also of other eminent Buddhist individuals. A closer and contextual reading of the text suggests that, instead of just providing a description of different places and regions in Central Asia with a Buddhist flavor, Xuanzang is driven by the educational agenda of informing the emperor about

42 Édouard Chavannes, "Les inscriptions chinoises de Bodh-Gayâ aux Xe et XIe siècles," Revue de l'histoire des religions 34, no. 1 (1896): 26-29; Tansen Sen, "In Search of Longevity and Good Karma: Chinese Diplomatic Missions to Middle India in the Seventh Century," Journal of World History 12, no. 1 (2001), 14-22.

43 Sylvain Lévi, “Les Missions de Wang Hiuen-ts'e dans l'Inde,” Journal Asiatique, 9th ser., 15 (1900): 304-305.

44 Lévi, “Les Missions de Wang Hiuen-ts'e dans l’Inde," 319-321.

45 See Max Deeg, Miscellanae Nepalicae: Early Chinese Reports on Nepal: The Foundation Legend of Nepal in its Trans-Himalayan Context (Lumbinī: Lumbinī International Research Institute, 2016), 33. At Longmen, there also exist inscriptions of Wang Xuance's brother and of the monk Xuanzhao, whom Wang brought back from India to China.

46 Lévi, “Les Missions de Wang Hiuen-ts'e dans l'Inde”; Sen, Buddhism, Diplomacy, and Trade, 15-25; Deeg, Miscellanae Nepalicae, 32-33. 
the strong presence of Buddhism in certain areas and the ideal (or rather idealized) situation of the religion under the rule of Buddhist kings, particularly Harșa Sīlāditya of Kanauj, or about the rather unfortunate destiny of kings who turned against the dharma. ${ }^{47}$

Xuanzang's "Record" is usually considered to be innovative and exceptional, but there are elements that clearly stand not only in the tradition of the zhuan in the dynastic histories, but also follow the previously discussed compendiums of the Sui period. This becomes clear when one looks for the model and origin of the rather extensive general description of India in the first half of the second fascicle of the "Record"; it contains subchapters, though not marked as such, on the following subjects: ${ }^{48}$

- The names of India

- The general geographical situation

- Measures of distance

- Measures of time

- Settlements and residences

- Outer appearance, clothes, and adornment

- Hygiene and purity

- The writing system

- Official documents

- General education and knowledge

- The four Vedas

- Teachers and scholars

- Buddhist learning and Buddhist institutions

- The caste system

- The military system

- The legal system

- Etiquette and behavior

- Illness and medical care

- Death and funerary customs

- Administration and taxation

- Agriculture and products

- Food and drinks

47 See Max Deeg, "Writing for the Emperor - Xuanzang Between Piety, Religious Propaganda, Intelligence, and Modern Imagination,” in Pāsādikadānaṃ: Festschrift für Bhikkhu Pāsādika, eds. Martin Straube et al. (Marburg: Indica et Tibetica Verlag, 2009), 30-60.

48 A full English translation and detailed commentary of this general description of India will be given in my forthcoming translation and commentary of the Datang-Xiyu-ji (publication planned for 2021). 
- Utensils and tools for preparing and eating food

- Precious items and money

- Climate

This clearly recalls the structure Yancong's Dasui-xiguo-zhuan, which was divided into ten thematic chapters on: 1. products; 2 . seasons; 3. dwellings; 4. governmental affairs; 5. teachings (religions); 6. etiquette; 7 . eating and drinking; 8. clothing; 9. jewelry [and] money; 10. mountains, rivers, kingdoms, cities, [and] people.

The predominance of Xuanzang's "Record" is not only reflected in its use as a source for official history writing, but also by the position it held in Chinese Buddhist historiographies. The Fozu-tongji 佛祖統紀, “General Records of the Buddhist Patriarchs,” compiled by Zhipan 志磐 (fl. 1258-1269), lists most of the well-known Buddhist travelers before and after Xuanzang, but only mentions the records of the two famous Tang monks Xuanzang and Yijing, even omitting Faxian's travelogue. ${ }^{49}$ Over time, Xuanzang's "Record"

49 T.2035.464b.27ff. Xitian-qiufa 西天求法, “[On Those Who] Searched for the Dharma in West India.” Note that Xitian is not to be taken in the literary sense, but means India (Tian) in the Western Regions (xiyu): 魏高貴鄉公 : 沙門朱士西遊于闐, 得放光般若。晉安帝: 沙門法顯自西域, 往五 天竺, 得經像, 泛南海而還。宋高祖 : 晊無竭往西竺, 二十年還, 揚 都譯經O後廢帝 : 沙門法獻 西遊于闐, 得提婆品 $\mathrm{O}$ 梁沙門智宣往西竺, 得梵經還。陳宣帝 : 沙門智圓往西竺, 隋文帝時得梵 經還。北魏孝明 : 遣使者宋雲沙門法力往西天, 得梵經百七十部還。北齊後主 : 沙門寶暹等往西 天, 得梵本還。隋文帝: 陳朝沙門智周等西竺求經還。唐太宗 : 勅李義表王元策使西竺, 登耆 山, 刻碑, 紀唐威德O玄牀三藏自西天求經還, 召見詔撰西域記。O武后 : 初義淨三藏自南海附 舶, 往西竺求法, 至是將梵本, 寄佛逝國, 述南海寄歸傳、求法高僧傳O玄宗 : 沙門惠日往西天 還, 召見說法, 賜號慈慗三藏法師 $\mathrm{O}$ 梁太祖 : 沙門智宣往西竺, 求經還, 進佛骨、梵經。O 宋太 祖 : 沙門道圓遊五天丛還, 進舍利、梵經O沙門行勤等應詔往西答, 求法, 所經諸國並賜詔書, 令遣人前導O沙門建盛自西筑還, 進貝葉梵經O真宗 : 開封府陳恕言 : 沙門往西天取經者, 宜察 人材O仁宗 : 沙門懷問乞往西竺, 為今上建塔於佛金剛座側O沙門懷問、得濟、永定等自中天竺 還, 進佛骨舍利、貝葉梵經、西天碑十九本。“Under the [rule] of the noble prince of the Wei, śramana Zhu Shi[xing] traveled westward to Khotan in order to get hold of the 'Light-Emitting Prajñā [pāramitā-sūtra]'. The śramaṇa Faxian, [under the reign] of Jin Andi (r. 382-419), went from the Western Regions to the Five Indias in order to obtain sūtras and statues, sailed across the Southern Ocean and returned [to China]. [During the reign] of Song Gaozu (r. 420-422), Tanwujie went to Western India and after twenty years returned to Yangdu (Nanjing) to translate sūtras. After the emperor had been dethroned, the śramana Faxian traveled westward to Khotan to obtain the Tipo-pin (Mohebanruoboluomi-hengjiatipo-pin 摩訶般若波羅蜜恒伽提婆品, T.227.568b.7ff., translated by Kumārajīva). - The śramaṇa Zhixuan of the Liang [dynasty] (502-587) traveled to Western India to obtain Sanskrit sūtras and returned [to China]. [During the reign of] Xuandi of the Chen [dynasty] (r. 563-582), the śramana Zhiyuan went to Western India, [and during] the time of Sui Wendi (r. 581-604), [he] obtained Sanskrit sūtras and returned [to China]. [During the era] Xiaoming of the Western Wei [dynasty] (r. 510-528), the envoy Song Yun [and] Fali were 
overwrote most of the previous and later travelogues and other descriptions of the "Western Regions" 50 - presumably one of the reasons that so many of them were lost or only preserved as fragments.

The Buddhist activities in this field certainly had an impact on non-Buddhist Chinese writing on foreign regions, and I will again take India as my point of reference to briefly demonstrate this influence. As already observed for the Sui period, the new dynasty of the Tang, with its obvious imperial and expansionist ambitions, was very interested in information about the Western Regions, which first expressed itself in a period of extreme productivity of compiling the official histories of preceding dynasties with the respective ethno-geographical chapters

dispatched to Western India to obtain Sanskrit sūtras, [and they] returned with 170 [texts]. [During the reign of] the last ruler of the Northern Qi (r. 565-577), the śramana Baoxian and others went to Western India to obtain Sanskrit sūtras and returned [to China]. [During the reign of] Sui Wendi (r. 581-604), the śramana Zhizhou of the court of the Chen and others searched for sūtras in Western India and returned [to China]. Tang Taizong ordered Li Yibiao [and] Wang Yuan[Xuan]ce on a mission to Western India, [during which they] ascended Mount Grdhrakūța and inscribed a stone tablet commemorating the power and virtues of the Tang. - Tripițaka Xuanzang [went] to search for sūtras in Western India and returned [to China]; [he] had an audience with the emperor, [who] ordered him to compile the 'Record of the Western Regions'. - [During the reign] of [empress] dowager Wu [Zetian] (r. 690-705), Yijing embarked on a boat from the Southern Ocean and went to Western India to search for sūtras, then dispatched Sanskrit to the kingdom of [Śrī] Bhoja, the 'Record Sent Back from the Southern Ocean' (Nanhai-jigui[-neifa]-zhuan) [and] the 'Biographies of Eminent Monks Searching for the Dharma' (Qiufa-gaoseng-zhuan). - [During the reign of] Xuanzong (r. 712-756), the śramana Huiri went to the Five Indias and returned [to China], had an audience with the emperor to preach the dharma, and was bestowed with the name 'Tripitaka Dharma-Master Compassion (Cimin)'. - [During the reign] of Liang Taizu (r. 907-923), the śramana Zhixuan went to Western India to search for sūtras and returned [to China], submitting to the throne bones of the Buddha and Sanskrit sūtras. [During the reign of] Song Taizu (r. 960-976), the śramana Daoyuan traveled to the Five Indias and returned [to China], submitting to the throne relics [and] Sanskrit sūtras. - The śramana Xingqing and others went to Western India on imperial order to search for sutras and presented imperial letters to all the kingdoms they passed through, ordering that the envoys should be guided. - The śramaṇa Jiancheng returned from Western India and presented to the throne Sanskrit sūtra manuscripts (pattra). - [During the rule of] Zhenzong (r. 997-1022), the governor of Kaifeng, Chen Shu, declared that śramanas going westward to fetch sutras should be scrutinized with regard to their qualities. - [During the rule of] Renzong (r. 1023-1063), the śramana Huaiwen asked [for permission] to go to Western India and to build a stūpa for the present emperor next to the Diamond Throne. - The śramanas Huaiwen, Deji, Yongding, and others returned from Central India and submitted to the throne Buddha bone relics, Sanskrit sūtra manuscripts, and nineteen inscriptions from Western India.”

50 Such as, for instance, Daoxuan's 道宣 (596-667) compilation Shijia-fangzhi 釋迦方志, [Record of the Regions of Śākya[muni]]; see Janine Nicol, "Daoxuan (c. 596-667) and the Creation of a Buddhist Sacred Geography of China: An Examination of the Shijia fangzhi 釋迦方志” (PhD diss., SOAS University of London, 2016). 
between 622 and 650 . What most of the previous dynasties had not done, namely the writing of the dynastic history of the preceding house of rulers, was promoted particularly under the second Tang emperor, Taizong, shortly after he ascended the throne in 626. I give a list of the dynastic histories compiled during this period with the high officials in charge and, if included, the chapters on the "Western Regions" and the respective countries or kingdoms. ${ }^{51}$

Compared with previous dynastic histories, we can see an increase in information about the Western Regions, however with a rather anachronistic and cumulative approach and a slightly chaotic presentation; the most extensive and latest of these works, the Beishi, also includes names of "obscure and otherwise unknown states and tribes." 52 The Nanshi, then, for the first time, includes a brief description of Central India, Zhong-Tianzhu 中天矢, while the Beishi extends the "Western Regions" to areas that were not previously included, but only refers to South India (Nan-Tianzhu 南天竺).

It was exactly in the middle of this busy period of establishing and compiling the dynastic histories of the previous dynasties that Taizong ordered Xuanzang to write his Datang-Xiyu-ji when he arrived back in China in 645. His description

51 I shall not give the complete list of Central Asian countries in each text here, but quite randomly select only those adjacent to or at the periphery of South Asia: Chenshu 陳書, 622-629 (636), compiled by Yao Cha 姚察 and Yao Silian 姚思廉; -. Beiqishu 北齊書, 627-636 (636), compiled by Li Delin 李德林 and Li Boyao 李百藥; -. Liangshu 梁書, 628-635 (636), compiled by Yao Cha and Yao Silian; -. Zhoushu 周書, 629 (636), compiled by Linghu Defen 令狐德荣: chapter 50, Yiyu 異域 2, has paragraphs on the Turks (Tujue 突厥), the Hephthalites (Yeda 囐噠), the Sogdians (Sute 粟特), the Parthians (Anxi 安息), and Persia (Bosi 波斯), but nothing on India. Suishu 隋書, 629-636 (636), compiled by Wei Zheng 魏徵: chapter 83, Xiyu 西域, has paragraphs on the Tuyuhun 吐谷渾, Tokharistan (Tuhuoluo 吐火羅), the Hephthalites (Yida 挹怛), and Persia (Bosi 波斯), and in chapter 84, Beidi 北狄 on the Turks (Tujue 突厥) and the Western Turks (XiTujue 西突厥), but nothing on India. Jinshu 晉書, 644 (646), compiled by Fang Xuanling 房玄齡: chapter 67, Siyi-zhuan 四夷傳, Xirong 西戎, has paragraphs on the Tuyuhun 吐谷渾, Ferghana (Dayuan 大宛), and Syria/Byzantium (Daqin 大秦), but nothing on India. Nanshi 南史, 630-650 (659), compiled by Li Yanshou 李延壽: Yimo 1 夷貊上, aside from Southeast Asian countries, contains paragraphs on Zhong-Tianzhu 中天笈 (Central India), Tianzhu-Jiapili 天竺迦毗黎 (IndiaKapila[vastu]?), and Shizi 師子 (Siṃha[ladvīpa] = Śrī Lañkā). Beishi 北史, 630-650 (659), compiled by Li Yanshou: chapter 97, Xiyu 西域, contains a long list of Central Asian countries/kingdoms, paragraphs on the Sogdians (Sute 粟特), Persia (Bosi 波斯), the territories of the five yabghus (xihou 翕侯) in Bactria and adjacent regions, Syria/Byzantium (Daqin 大秦), Jibin 罰賓 (in this context Kāpisisi), Tokharistan (mentioned twice, once as Tuhuluo 吐呼羅 [sic] and later as Tuhuoluo 吐火羅), South India (Nan-Tianzhu 南天竺), the Hephthalites (Yeda 触噠), Udyāna/ Swāt (Wuchang 鳥萇), Gandhāra (Gantuo 乾陀 [sic]), and Bāmiyān (Yinhan 吲汗). On the dynastic histories, see Endymion Wilkinson, Chinese History: A Manual, rev. ed., Harvard Yenching Institute Monograph Series 52 (Cambridge, MA: Harvard University Press, 2000), 503-504.

52 Hans Bielenstein, Diplomacy and Trade in the Chinese World, 2. 
of the "Western Regions" that comprised India became the standard model for generations, and while it may already have influenced the compilers of the Nanshi and the Beishi in their decision to include India, it definitely left its traces in the extensive list of "Western Regions" in the Beishi.

By the time of the compilation of the Older Tang History (Jiu-Tangshu 舊唐書), compiled between 940 and 945 under the supervision of $\mathrm{Liu} \mathrm{Ju}$ 劉呴 (888-947), Xuanzang's description of India already had made such a great impact that the record can be seen to rely heavily on the information given in the Xiyu-ji, ${ }^{53}$ but obviously also contains information gained from other sources:

The kingdom of India (Tianzhu 天竺) is the kingdom of Shendu 身毒 of the Han [dynasty], also called "the land of the brāhmana" (bolouomen 婆羅門). Having the "Onion Mountains" (Karakorum-Pamir) to its northwest, it encompasses more than thirty thousand $l i$. It is divided into the Five Indias, the first one called Central India, the second East India, the third South India, the fourth West India, [and] the fifth North India. Each region [has a circumference of] several thousand $l$, [and] there are several hundreds of cities and towns. South India adjoins the Great Ocean; North India extends to the "Snow Mountains" (Himālaya), [and] there are mountains everywhere, forming a wall; in southern direction, it faces one valley, which forms the gateway to the kingdom; ${ }^{54}$ East India borders the Great Ocean to the east and has common borders with Fu'nan (扶南: South Vietnam) and Linyi (Central Vietnam); West India is connected with Jibin (罣賓, here Kāpīsii) and Persia; Central India is linked with all the [other] four Indias; its capital has a circumference of more than seventy $l$, and in the north [it] is adjacent to the river Chanlian (Nairañjanā). It is said that formerly there was a brāhmaṇa, the leader of a thousand followers, [who] practiced under a tree; the tree goddess came down, and they finally became husband and wife. A palace appeared miraculously, full of young servants. Thereupon [the brāhmaña] had a hundred deities build a city to rule over it, and after one day it was accomplished. Later, King Aśoka again had a ghost pile up rocks into a palace and chisel patterns and statues [out of the rocks]. No human would have had the power to do this. King Aśoka rather ruled with terror, established the punishment of burning, and called [the place] "Hell"; nowadays, traces of it are still visible. The kings of Central India are of the class of the qilidie (乞利咥) clans, also called chali 刹利 clans; ${ }^{55}$ [they] have ruled this kingdom for generations, [and] there has been no regicide. This land is humid and hot, [and] the rice matures four [times] a year; there are diamonds similar to amethysts [that] do not melt [even if one] tempers them a hundred times, [but one] can cut jade with it. There is also incense like sandal[wood]

53 Due to lack of space, I am not able go into a detailed analysis of the text and its relation to the Xiyu-ji, and some notes may suffice here to demonstrate how the text was compiled. Detailed information and discussion will be given in my translation and commentary of the second fascicle of the Xiyu-ji (publication planned for 2021).

54 This is taken from the description of Kaśmīr and transferred to North India as a whole.

55 This is a wrong combination of details taken from Xuanzang: chali is an older form of the term for kșatriya, for which Xuanzang suggests chadili 刹帝利 (T.2087.877b.4f.); qilidie 乞利咥 seems to be a corruption of Xuanzang’s qiliduo 訖利多 / ${ }^{\star} k i t-l h^{h}$-ta, the name of a previous ruling dynasty of Kaśmìr, the Krīta (T.2087.886b.9f. et passim). 
(zhantan 斿檀) [or] turmeric (yujin 郁金); because [the trade] goes through Daqin (大秦: SyriaByzantium), its treasures [are] sometimes [traded] all the way to Fu'nan [and] Jiaozhi (交趾: Northern Vietnam). ${ }^{56}$ The people are wealthy and happy, [and their] customs are not recorded. Those who cultivate the royal land contribute to the fecundity [of it]. [People] use cowry as currency. The people have deep-set eyes, long noses, and [when they] pay the ultimate respect, [they] lick the feet and rub the heels [of the high person]. [In each] household, there are some musicians and dancers. The king and the high officials mostly dress in brocade and felt; [they] twist the [hair on their crest and] cut the rest of the hair to a curl. The common people all walk barefoot, [and their] clothes [are] of a pure white [color]. Only the members of the caste of the brahmacārin drape a white cotton [shawl around their shoulders] to distinguish themselves [from the others]. When [someone] dies, [they] either burn the corpse and collect the ashes and make a stūpa (futu 浮圖) [for it], expose [the corpse] in an open field to give it to the wild animals, or [they] let it flow in the river to feed the fish and turtles. They do not have funeral epitaphs. Those who plot a rebellion are killed secretly; minor criminal offenses [are punished by] a monetary fine to atone for one's crime. For impious behavior (buxiao 不孝), hands and feet are cut off, ears and nose are severed, [and the perpetrators] are sent off [into exile] outside of the border. ${ }^{57}$ They have writing and are skilled in astronomy and calendrical arithmetic. The people of this [land] all study the "Siddham Chapter" (Xitan-zhang 悉暑章), [which] is said to be the way of god Brahmā. To [compose] records, [they] write on the leaves of the aśvattha tree (beiduo-shu 貝多樹). [They] do not kill living beings, [and] everywhere in the kingdom, there are ancient traces of the Buddha. ${ }^{58}$

\section{Despite this obvious dependence on Xuanzang, it is interesting to see how the compilers of the text used the vast amount of information contained in the}

56 This remark seems to reflect some concern about long-distance trade between the Levant and Southeast Asia going via South Asia rather than using the Silk Road through China.

57 This description of the Indian law and penal system is a digest of Xuanzang's record in the second fascicle of the Xiyu-ji; see Max Deeg, "Indian Law from a Seventh Century Chinese Buddhist Perspective,” Bulletin de l'École Franşaise de l'Extrême-Orient 105 (2019): 19-49.

58 Jiu-Tangshu 198, Xirong 西戎, “Western Barabarians”: 天竺國, 即漢之身毒國, 或云婆羅 門地也。在葱嶺西北, 周三萬餘里。其中分為五天竺: 其一曰中天笨天答, 三曰南天 竺, 四曰西天竺, 五曰北天竺。地各數千里, 城邑數百。南天竺際大海, 北天答拒雪山, 四周 有山為壁, 南面一谷, 通為國門; 東天竺東際大海, 與扶南、林邑鄰接; 西天竺與罰賓、波斯 相接; 中天竺據四天竺之會, 其都城周回七十餘里, 北臨禪連河。云昔有婆羅門領徒千人, 肄 業於樹下, 樹神降之, 遂為夫婦。宮室自然而立, 僮仆甚盛。於是使役百神, 築城以統之, 經 日而就。此後有阿育王, 復役使鬼神, 累石為宮關, 皆雕文刻鏤。非人力所及。阿育王頗行苛 政, 置砲烙之刑, 謂之地獄, 今城中見有其跡焉。中天竺王姓乞利咥氏, 或云刹利氏, 世有 其國, 不相篡斌。厥土卑濕暑熱, 稻歲四熟, 有金剛, 似紫石英, 百煉不銷, 可以切玉。又有 斿檀、郁金諸香。通於大秦, 故其寶物或至扶南、交趾貿易焉。百姓殷樂, 俗無簿籍, 耕王地 者輸地利。以齒貝為貨。人皆深目長鼻。致敬極者, 舐足摩踵。家有奇樂倡伎。其王與大臣多 服錦䍔。上為螺䯽於頂, 餘髮翦之使拳。俗皆徒跣。衣重白色, 唯梵誌種姓披白疊以為異。死 者或焚屍取灰, 以為浮圖; 或委之中野, 以施禽獸; 或流之於河, 以飼魚鱉。無喪紀之文。謀 反者幽殺之, 小犯罰錢以贖罪。不孝則斷手刖足, 截耳割鼻, 放流邊外。有文字, 善天文算歷 之術。其人皆學《悉昙章》, 云是梵天法。書於貝多樹葉以紀事。不殺生飲酒。國中往往有舊 佛跡。 
$X i y u-j i$ in quite a selective way: probably in order to adapt it to the established genre of Chinese historiographical writing, the Xiyu-ji's heavy focus in the on all things Buddhist is given up - instead, the text mentions Brahminic ascetics (fanzhi 梵誌, brahmacārin) and the god Brahmā (Fan-tian 梵天) - and the information about Buddhism is kept to a minimum (sacred traces of the Buddha), or shifted in favor of a "traditional" focus on productivity and customs. It is striking that the stūpa (futu 浮圖) is deprived of its Buddhist symbolism and turned into a general "tomb," and that the paradigmatic Buddhist king Aśoka is presented only as a despotic ruler, without mentioning his later conversion and pro-Buddhist actions.

It is the nature of the Buddhist travelogues to focus on the Buddhist sacred landscape and to give only the most necessary information about the natural, social, political, and economic conditions of the respective regions. How much information is given seems to depend on the audience: while travelers like Faxian and Huichao wrote for a Buddhist readership and could restrict the more secular data to a minimum, authors like Song Yun and Xuanzang, as well as writers collating information about India and other "Western Regions" from different sources without having traveled themselves, had to provide more such data due to the semiofficial or official nature of their reports. Buddhist travelogues had a "reassuring" function for Chinese Buddhists: despite the fact that most of them lived in what the Buddhist worldview would call an inferior "borderland," they were part of a Buddhist sacred geography with its center in Central India. India was thus the "other," but at the same time, it was a defining part of their own position in a soteriologically meaningful world. Later secular historiographers then used the material and the information that they found in the Buddhist travelogues, but were less interested in the specific Buddhist and religious features of these records; they reduced the Buddhist way of describing "the own other" to a mere description of the (Indian) other and thereby, in a way, turned the description back into a traditional Chinese secular mode of recording.

\section{Bibliography}

Bielenstein, Hans. Diplomacy and Trade in the Chinese World, 589-1276. Handbook of Oriental Studies 4.18. Leiden: Brill, 2005.

Boulton, Nancy Elizabeth. Early Chinese Buddhist Travel Records as a Literary Genre. 2 vols. PhD diss., Georgetown University, 1982.

Chavannes, Édouard. “Les inscriptions chinoises de Bodh-Gayâ aux Xe et Xle siècles.” Revue de l'histoire des religions 34, no. 1 (1896): 1-58. 
Chavannes, Édouard. “Voyage de Song Yun dans l'Udyāna et le Gandhāra (518-522 p.C.).” Bulletin de l'École Française de l'Extrême-Orient 3 (1903): 379-441.

Deeg, Max. Das Gaoseng-Faxian-zhuan als religionsgeschichtliche Quelle. Der älteste Bericht eines chinesischen buddhistischen Pilgermönchs über seine Reise nach Indien mit Übersetzung des Textes. Studies in Oriental Religions 52. Wiesbaden: Otto Harrassowitz, 2005.

Deeg, Max. "Was haben ein Mönch und Fisch gemeinsam? Monastische Regeln und Lebensrealität und der Aussagewert der chinesischen Pilgerberichte." In Im Dickicht der Gebote: Studien zur Dialektik von Norm und Praxis in der Buddhismusgeschichte Asiens, Historia Religionum 26, edited by Peter Schalk, 99-152. Uppsala: Uppsala Universitet, 2005.

Deeg, Max. "Has Xuanzang Really Been in Mathurā? Interpretatio Sinica or Interpretatio Occidentalia - How to Read Critically the Records of the Chinese Pilgrims." In Essays on East Asian Religion and Culture. Festschrift in Honour of Nishiwaki Tsuneki on the Occasion of his 65th Birthday, edited by Christian Wittern and Shi Lishan, 35-73. Kyoto: Editorial Committee for the Festschrift in Honour of Nishiwaki Tsuneki, 2007.

Deeg, Max. "Mapping Common Territory - Mapping Other Territory." Acta Orientalia Vilniensia 8, no. 1 (2008): 145-161.

Deeg, Max. "Writing for the Emperor - Xuanzang Between Piety, Religious Propaganda, Intelligence, and Modern Imagination." In Pāsādikadānaṃ: Festschrift für Bhikkhu Pāsādika, edited by Martin Straube, Roland Steiner, Jayandra Soni, Michael Hahn, and Mitsuyo Demoto, 30-60. Marburg: Indica et Tibetica Verlag, 2009.

Deeg, Max. "Zwischen Spannung und Harmonie: Das Problem von Chronologie und Synchronologie in der frühen chinesischen buddhistischen Historiographie." In Geschichten und Geschichte. Historiographie und Hagiographie in der asiatischen Religionsgeschichte, edited by Peter Schalk, 96-139. Uppsala: Uppsala Universitet, 2010.

Deeg, Max. “When Peregrinus Is Not Pilgrim: The Chinese 'Pilgrims' Records - A Revision of Literary Genre and its Context." In Dharmayātra - Buddhist Pilgrimage in Time and Space, edited by Christoph Cueppers and Max Deeg, 65-95. Lumbinī: Lumbinī International Research Institute, 2014.

Deeg, Max. Miscellanae Nepalicae: Early Chinese Reports on Nepal: The Foundation Legend of Nepal in its Trans-Himalayan Context. Lumbinī: Lumbinī International Research Institute, 2016.

Deeg, Max. (=Ning Fanfu 宁梵夫). “Chongu ‘biandi qingjie’: Han chuan fojiao zhong dui Yindu de zhujian rongshou” 重估“边地情结”: 汉传佛教中对印度的逐渐容受 [“Borderland complex" reloaded: Coming to terms with India in Chinese Buddhism]. In Zhongyin guanxi yanjiu de shiye yu qianjing 中印关系研究的视野与前景, edited by Shen Dansen 沈丹森 (Tansen Sen) and Sun Yinggang 孙英刚, 65-76. Shanghai: Fudan-daxuechubanshe 復旦出版社, 2016.

Deeg, Max. “Indian Law from a Seventh Century Chinese Buddhist Perspective." Bulletin de l'École Française de l'Extrême-Orient 105 (2019): 19-49.

Held, Axel. “Der buddhistische Mönch Yen-Ts'ung (557-610) und seine Übersetzungstheorie. PhD diss., University of Cologne, 1972.

Hill, John E. Through the Jade Gate - China to Rome: A Study of the Silk Routes 1st to 2nd Centuries CE: An Annotated Translation from the Hou Hanshu, "The Chronicle on the Western Regions," rev. ed. 2 vols. N.p.: John E. Hill, 2015. 
Jäger, Fritz. “Leben und Werk des P’ei Kü.” Ostasiatische Zeitschrift 9 (1920-1922): 81-115, 216-231.

Karttunen, Klaus. India in Early Greek Literature. Studia Orientalia 65. Helsinki: Finnish Oriental Society, 1989.

Karttunen, Klaus. India and the Hellenistic World. Studia Orientalia 83. Helsinki: Finnish Oriental Society, 1997.

Lévi, Sylvain. “Les Missions de Wang Hiuen-ts'e dans l'Inde.” Journal Asiatique, 9th ser., 15 (1900): 297-341, 401-468.

Lopez, Jr., Donald S. Hyecho's Journey: The World of Buddhism. Chicago: University of Chicago Press, 2017.

Lourme, Jean Marie. Yang Xuanzhi: Mémoire sur les monastères bouddhiques de Luoyang. Paris: Les Belles Lettres, 2014.

Nattier, Jan. Once upon a Future Time: Studies in a Buddhist Prophecy of Decline. Berkeley: Asian Humanities Press, 1991.

Needham, Joseph. Science and Civilisation in China. Vol. 2, History of Scientific Thought. Cambridge: Cambridge University Press, 1956.

Nicol, Janine. "Daoxuan (c. 596-667) and the Creation of a Buddhist Sacred Geography of China: An Examination of the Shijia fangzhi 釋迦方志." PhD diss., SOAS University of London, 2016.

Petech, Luciano. Northern India according to the Shui-Ching-Chu. Serie Orientale Roma 2. Rome: Is.M.E.O., 1950.

Petech, Luciano. “La Description des pays d'occident de Che Tao-ngan.” In Mélanges de sinologie offerts à Monsieur Paul Demiéville, vol. 1, 167-190. Paris: Presses Universitaires de France, 1966.

Petech, Luciano. “Note additionelle sur la 'Description des pays d'occident' de Che Tao-ngan.” In Mélanges de sinologie offerts à Monsieur Paul Demiéville, vol. 2, 399-401. Paris: Presses Universitaires de France, 1974.

Pulleyblank, Edwin G. Lexicon of Reconstructed Pronounciation in Early Middle Chinese, Late Middle Chinese, and Early Mandarin. Vancouver: University of British Columbia Press, 1991.

Rackham, Harris, ed. Pliny: Natural History. Vol. 2, Libri III-VII. Loeb Classical Library. Cambridge, MA: Harvard University Press, William Heinemann Ltd., 1961.

Sen, Tansen. "In Search of Longevity and Good Karma: Chinese Diplomatic Missions to Middle India in the Seventh Century." Journal of World History 12, no. 1 (2001): 1-28.

Sen, Tansen. Buddhism, Diplomacy, and Trade. The Realignment of Sino-Indian Relations, 600-1400. Honolulu: University of Hawai'i Press, 2003.

Sharf, Robert H. Coming to Terms with Chinese Buddhism: A Reading of the Treasure Store Treatise. Kuroda Institute Studies in East Asian Buddhism 14. Honolulu: University of Hawai'i Press, 2002.

Twitchett, Denis. The Writing of Official History Under the T'ang. Cambridge: Cambridge University Press, 1992.

Wang Bangwei 王邦維. Datang-xiyu-qiufa-gaoseng-zhuan-xiaozhu 大唐西域求法高僧傳校注. Beijing: Zhonghua-shuju 中華書局, 2009.

Wang Yi-t'ung. A Record of Buddhist Monasteries in Lo-yang by Yang Hsüan-chih. Princeton: Princeton University Press, 1984.

Wilkinson, Endymion. Chinese History: A Manual, rev. ed. Harvard Yenching Institute Monograph Series 52. Cambridge, MA: Harvard University Press, 2000. 
Wright, Arthur F. "The Sui dynasty (581-617)." In The Cambridge History of China, vol. 3, Sui and T'ang China, 589-906, Part l, edited by Denis Twitchett and John K. Fairbank, 48-149. London: Cambridge University Press, 1979.

Yang Han -Sung, Jan Yün-Hua, lida Shotaro, and Laurence W. Preston. The Hye Ch'o Diary: Memoir of the Pilgrimage to the Five Regions of India. Berkeley: Asian Humanities Press, 1984.

Zürcher, Erich. The Buddhist Conquest of China - The Spread and Adaptation of Buddhism in Early Medieval China, 3rd ed. Sinica Leidensia 11. Leiden: Brill, 2007. 